\title{
Effects of dietary levels of protein on nitrogenous metabolism of Rhamdia quelen (Teleostei: Pimelodidae)
}

\author{
José Fernando Bibiano Melo ${ }^{\mathrm{a}}$, Lícia Maria Lundstedt ${ }^{\mathrm{b}}$, Isidoro Metón ${ }^{\mathrm{c}}$, \\ Isabel Vázquez Baanante ${ }^{\mathrm{c}}$, Gilberto Moraes ${ }^{\mathrm{b}, *}$ \\ ${ }^{a}$ Department Science and Technology, University of Bahia, Juazeiro, BA, Brazil \\ ${ }^{\mathrm{b}}$ Department of Genetics and Evolution, Federal University of Sao Carlos, Sao Carlos, SP, Brazil \\ ${ }^{\mathrm{c}}$ Departament de Bioquímica i Biologia Molecular, Facultat de Farmàcia, Universitat de Barcelona, Barcelona, Spain
}

Received 21 January 2006; received in revised form 8 June 2006; accepted 9 June 2006

Available online 10 June 2006

\begin{abstract}
This manuscript reports changes in key enzymes and metabolites related to protein metabolism and nitrogen excretion in the liver of juveniles jundiá (Rhamdia quelen) fed on isocaloric diets containing $20 \%, 27 \%, 34 \%$ and $41 \%$ of crude protein. The hepatic activity of alanine aminotransferase (ALAT), aspartate aminotransferase (ASAT), glutamate dehydrogenase (GDH), and arginase (ARG) increased with the content of protein in the diet, and the ratios among the aminotransferases and GDH allowed evaluating metabolic preference. The concentration of free amino acids, ammonia and urea also rose with the dietary protein content. Increase of plasma urea and ammonia was the resultant effect of over amino acids catabolism as consequence of dietary protein surplus. Since the increase of protein in the diets resulted in weight gain, the rise in the hepatic activity of protein-metabolising enzymes in the fish fed high protein diets denoted effective use of dietary amino acids for growth and as a substrate for gluconeogenesis. Analysis of changes on metabolite levels and key enzyme activities in amino acid metabolism is proposed as a tool for assessing the proper balance of diet macronutrients.

(C) 2006 Elsevier Inc. All rights reserved.
\end{abstract}

Keywords: Metabolism; Crude protein; Jundiá; Rhamdia quelen; ALAT; ASAT; GDH; Arginase

\section{Introduction}

Fishes use amino acid carbon backbone not only for building proteins, but also for synthesis of sugars and fats (Wood, 1993). Metabolic pathways for amino acids, sugars and fats catabolism were firstly studied in mammals. However, the effects of dietary nutrients on the intermediary metabolism of teleost fishes remain scarcely known as compared to mammals.

In carnivorous fish glucose is usually synthesized from amino acids via gluconeogenesis (Cowey et al., 1977). In several species, glycogen mobilization is slow and glucose, for metabolic demands, is mainly obtained from amino acids. However, it is expected that omnivorous fishes can utilize carbohydrates more easily than carnivorous fish. The set of enzymes related to

\footnotetext{
* Corresponding author. Rod. Washington Luiz Km 235. CEP 13565-905. Sao Carlos, SP, Brazil. Tel.: +55 1633518376 .

E-mail address: gil@power.ufscar.br (G. Moraes).
}

both nutrient groups, sugar and protein, should be likely distinct concerning responses to dietary changes in both groups of fish. There are many reports concerning the direct relationship among enzymes of energetic metabolism, protein metabolism and the nutritional status (Baanante et al., 1991; Bonamusa et al., 1992; Moon and Foster, 1995; Metón et al., 1999).

In feeding fish, increasing contents of protein usually result in a rise in the growth rate. This is directly correlated to the increase in oxidative metabolism and protein synthesis likely as consequence of amino acids surplus and due to hormonal effects (Houlihan et al., 1993). The amino acids surplus from protein-rich diets cannot be directly stored in fishes; they are deaminated and converted into energetic compounds (Ballantyne, 2001; Stone et al., 2003).

The expression of key enzymes of intermediary metabolism is modulated by nutritional status in fish (Metón et al., 1999, 2003). In this regard, the levels of amino acid-metabolising enzymes and nitrogen excretion are reliable indicators of dietary protein 
availability. Increase in arginase activity is directly associated with protein in the diet of Salmo salar (Lall et al., 1994). The rise of protein catabolism due to high protein in diets has been also detected through the plasma concentration of free metabolic intermediates, such as amino acids (Ogata and Arai, 1985). In addition, low digestibility of the energetic foods increases nitrogenous excretion (Steffens, 1989).

Metabolism of carnivorous fish is adapted to high levels of dietary protein. By contrast, low ability of using sugars is reported (Cowey and Walton, 1989; Caseras et al., 2000; Lundstedt et al., 2004). Chinook salmon Oncorhynchus tshawytscha was likely the first fish species studied on the protein demands (De Long et al., 1958). Afterwards, many other species, including omnivorous species, were studied and the protein requirement ranged around $22-40 \%$ for catfish Ictalurus punctatus (Garling and Wilson, 1976); 34\% for the tilapia Oreochromis aureus (Winfree and Stickney, 1981); 30\% for Nile tilapia Oreochromis niloticus; $40 \%$ for Mozambique tilapia Oreochromis mosambicus (Jauncey, 1982 ) and $32-40 \%$ for Neotropical freshwater fish piracanjuba Brycon orbignyanus (Do Carmo de Sá and Fracalossi, 2002) and Pseudoplatystoma corruscans (Lundstedt et al., 2004). Previously, we have observed that changes in the metabolic profile are a tool to assess the fish performance and ability to cope with different dietary conditions (Bidinotto and Moraes, 2000; Moraes and Bidinotto, 2004; Lundstedt et al., 2004). At present, most studies on fish protein requirements and metabolism are concerned with models for marine carnivorous coldwater fish. Therefore, knowledge on biochemical features in the warm freshwater fish will provide the basis for better understanding on the handling and rearing of these species.

The study of nutritional demands and the effect of dietary nutrients in the intermediary metabolism of the South American freshwater catfish jundiá (Rhamdia quelen) are of particular interest due to the aquaculture characteristics of the species: $R$. quelen accepts artificial feeding from hatching, shows large survival rates and fast growth (Piaia and Radünz-Neto, 1997; Melo et al., 2002). Little information concerning digestion and metabolism of species from the genus Rhamdia is available. $R$. quelen is omnivorous and able to use numerous kinds and sources of nutrients. The present work reports adaptive metabolic adjustments of key metabolites and related enzymes of protein metabolism of $R$. quelen fed increasing contents of crude protein.

\section{Materials and methods}

\subsection{Experimental design}

Juveniles of jundiá (R. quelen) ranging $32.6 \pm 3.0 \mathrm{~g}$ (S.D.) from artificial reproduction were fed with $6-8 \mathrm{~mm}$ dry pellets for 60 days at a feeding rate of $10 \%$ of biomass, twice a day. Periodical evaluation of growth was done each 15 days to adjust to that fish rate of feeding. We used four isocaloric diets $(4,500 \mathrm{kcal}$ gross energy $/ \mathrm{kg})$ with $20 \%, 27 \%, 34 \%$ and $41 \%$ of crude protein $(\mathrm{CP})$ (Table 1$)$. Fish $(N=160)$ were equally divided into four fed groups and held in $2000 \mathrm{~L}$ tanks with thermoregulated water at $26 \pm 2{ }^{\circ} \mathrm{C}$, in a re-circulated closed system
Table 1

Ingredients and analyzed composition of the experimental diets (dry matter basis) for jundiá (Rhamdia quelen)

\begin{tabular}{|c|c|c|c|c|}
\hline & \multicolumn{4}{|c|}{ Experimental diets } \\
\hline & $20 \% \mathrm{CP}$ & $27 \% \mathrm{CP}$ & $34 \%$ CP & $41 \% \mathrm{CP}$ \\
\hline \multicolumn{5}{|l|}{ Ingredients $^{\mathrm{a}}(\%)$} \\
\hline Fish meal ${ }^{\mathrm{b}}$ & 14.2 & 24.2 & 19.2 & 35.2 \\
\hline Soy bran ${ }^{c}$ & 8.0 & 11.0 & 11.0 & 24.0 \\
\hline Yeast $^{\mathrm{d}}$ & 8.0 & 8.0 & 20.0 & 15.0 \\
\hline Corn $^{\mathrm{e}}$ & 38.0 & 30.0 & 26.0 & 8.0 \\
\hline Wheat bran ${ }^{\mathrm{f}}$ & 14.0 & 14.0 & 14.0 & 10.0 \\
\hline Vegetable oil ${ }^{\mathrm{g}}$ & 17.0 & 12.0 & 9.0 & 7.0 \\
\hline $\mathrm{NaCl}$ & 0.5 & 0.5 & 0.5 & 0.5 \\
\hline Vitamin mixture $^{\mathrm{h}}$ & 0.2 & 0.2 & 0.2 & 0.2 \\
\hline Mineral mixture ${ }^{\mathrm{i}}$ & 0.1 & 0.1 & 0.1 & 0.1 \\
\hline Vitamin C & 0.05 & 0.05 & 0.05 & 0.05 \\
\hline \multicolumn{5}{|l|}{ Chemical composition } \\
\hline Dry matter $(\%)$ & 90.06 & 89.81 & 89.61 & 90.74 \\
\hline Crude protein (\%) & 19.37 & 26.33 & 33.2 & 40.14 \\
\hline Gross energy $(\mathrm{kcal} / \mathrm{kg})$ & 4.419 & 4.610 & 4.504 & 4.438 \\
\hline Lipid (\%) & 18.57 & 14.76 & 11.98 & 9.70 \\
\hline Crude fiber (\%) & 3.24 & 3.24 & 3.14 & 3.92 \\
\hline Ash (\%) & 5.35 & 7.88 & 7.53 & 12.61 \\
\hline Carbohydrate $(\%)^{\mathrm{j}}$ & 43.53 & 38.60 & 32.50 & 24.37 \\
\hline
\end{tabular}

$\mathrm{CP}$ — crude protein; DM — dry matter; GE — gross energy; L — lipid; CF — crude fibre; $\mathrm{CHO}$ - carbohydrate as nitrogen free extract.

${ }^{a}$ Ingredients used in the composition of experimental diets were purchased from animal food companies in Sao Paulo State, Brazil.

${ }^{b}$ Fishmeal: $92.12 \%$ DM; $56.43 \%$ CP; $4100 \mathrm{kcal} \mathrm{GE;} \mathrm{4.45 \%} \mathrm{L;} \mathrm{0.34 \%} \mathrm{CF;}$ 21.4\% Ash; 9.5\% CHO.

${ }^{c}$ Soy Bran: 86.54\% DM; 46.02\% CP; 3010 kcal GE; 0.96\% L; 6.08\% CF; 5.41\% Ash; $28.07 \%$ CHO.

${ }^{d}$ Yeast: $92.12 \%$ DM; $56.43 \%$ CP; 3522 kcal GE; $4.45 \%$ L; $0.34 \%$ CF; $21.4 \%$ Ash; $9.5 \%$ CHO

e Corn: $87.8 \%$ DM, 7.17\% CP, 4004 kcal GE; 4.14\% L; $1.5 \%$ CF; $1.15 \%$ Ash; $73.84 \%$ CHO.

${ }^{\mathrm{f}}$ Wheat Bran: 96.99\% DM; 11.84\% CP; $2700 \mathrm{kcal} \mathrm{GE}$; 3.75\% L; 8.4\% CF; $4.82 \%$ Ash; 58.2 CHO.

g Soy bean oil 9,800 kcal GE.

${ }^{\text {h }}$ Composition of vitamin mixture/kg dietary: Vitamin A 10.000 UI, E $50 \mathrm{mg}$, $\mathrm{D}_{3} 2000 \mathrm{UI}, \mathrm{K}-325 \mathrm{mg}, \mathrm{B} 1250 \mathrm{mg}$, thiamine $15 \mathrm{mg}$, riboflavin $35 \mathrm{mg}$, pyridoxine $10 \mathrm{mg}$, biotin $250 \mathrm{mg}$, folic acid $5 \mathrm{mg}$, acid pantothenic $60 \mathrm{mg}$, niacin $60 \mathrm{mg}$, choline $120 \mathrm{~g}$. antioxidant $50 \mathrm{~g}$.

${ }^{\mathrm{i}}$ Composition of mineral mixture/ $\mathrm{kg}$ dietary: iron $40 \mathrm{mg}$, copper $12.5 \mathrm{mg}$, zinc $30 \mathrm{mg}$, cobalt $1 \mathrm{mg}$, iodine $1.4 \mathrm{mg}$ and selenium $0.2 \mathrm{mg}$.

${ }^{\mathrm{j}}$ Carbohydrate $(\%)=$ Dry Matter $-($ Crude Protein + Fat + Crude Fibre + Ash $)$.

provided with bio-filters. Water quality parameters were daily checked and kept within satisfactory range $(\mathrm{pH} 6.9 \pm 1.2$; dissolved oxygen $5.6 \pm 1.3 \mathrm{mg} / \mathrm{L} ; \mathrm{N}-\mathrm{NH}_{3} 0.14 \pm 0.04 \mathrm{mg} / \mathrm{L}$ ). Natural photoperiod was $14 \mathrm{~h}$ light. After 15 days, 10 fish per treatment were sampled, anaesthetized with benzocaine $(50 \mathrm{mg} / \mathrm{L})$ and killed by cervical punching. Liver were quickly excised, frozen in liquid nitrogen and kept at $-80^{\circ} \mathrm{C}$. The remaining fish $(n=30$ per tank) continued in the tanks for 45 days more and were sampled for biometry.

\subsection{Metabolites determination}

Liver was homogenized $(1: 10 \mathrm{w} / \mathrm{v})$ into $20 \%$ trichloroacetic acid (TCA acid extract) or in saline solution (neutral extracts). Metabolites were quantified in crude plasma and liver extracts. 
Table 2

Growth parameters of jundiá (Rhamdia quelen)

\begin{tabular}{|c|c|c|c|c|}
\hline & \multicolumn{4}{|c|}{ Dietary protein level (\%) } \\
\hline & $20 \% \mathrm{CP}$ & $27 \% \mathrm{CP}$ & $34 \% \mathrm{CP}$ & $41 \% \mathrm{CP}$ \\
\hline Mean initial mass (g) & $30.29 \pm 5.24$ & $33.23 \pm 7.86$ & $32.11 \pm 4.24$ & $29.23 \pm 6.07$ \\
\hline Initial biomass ( $\mathrm{g}$ ) & 1211 & 1329 & 1284 & 1169 \\
\hline Mean final mass (g) & $60.04 \pm 17.04^{\mathrm{d}}$ & $76.12 \pm 13.89^{c}$ & $87.64 \pm 11.71^{\mathrm{b}}$ & $101.17 \pm 17.58^{\mathrm{a}}$ \\
\hline Mean final length $(\mathrm{cm})$ & $18.52 \pm 2.14^{\mathrm{b}}$ & $19.67 \pm 1.51^{\mathrm{ab}}$ & $18.88 \pm 1.42^{\mathrm{ab}}$ & $20.91 \pm 1.78^{\mathrm{a}}$ \\
\hline Final biomass $(\mathrm{g})$ & 1801 & 2283 & 2629 & 3035 \\
\hline
\end{tabular}

CP: Crude Protein. Weight is expressed in grams, length in $\mathrm{cm}$ and weight gain in $\%$. Different letters in the same row signify statistical differences $(P<0.05)($ mean \pm S.D.). Weight gain $(\%)=[($ Mean Final Weight - Mean Initial Weight $) /$ Mean Initial Weight $] \times 100$.

Urea was determined at $525 \mathrm{~nm}$ in acid extract (Rahmatullah and Boyde, 1980). Glucose was determined at $340 \mathrm{~nm}$ by the glucose dehydrogenase method using a commercial kit (Roche). Free amino acids and ammonia were determined in neutral extracts at $570 \mathrm{~nm}$ (Copley, 1941) and $420 \mathrm{~nm}$ (Gentzkow and Masen, 1942), respectively.

\subsection{Enzyme assays}

Crude homogenates to assay enzyme activities were obtained by homogenization of powdered frozen liver $(1 / 5, \mathrm{~W} / \mathrm{V})$ into $50 \mathrm{mM}$ Tris- $\mathrm{HCl} \mathrm{pH} \mathrm{7.5,} 4$ mM EDTA (ethylenediamine tetraacetate), $50 \mathrm{mM} \mathrm{NaF}, 0.5 \mathrm{mM}$ PMSF (Phenylmethylsulfonyl

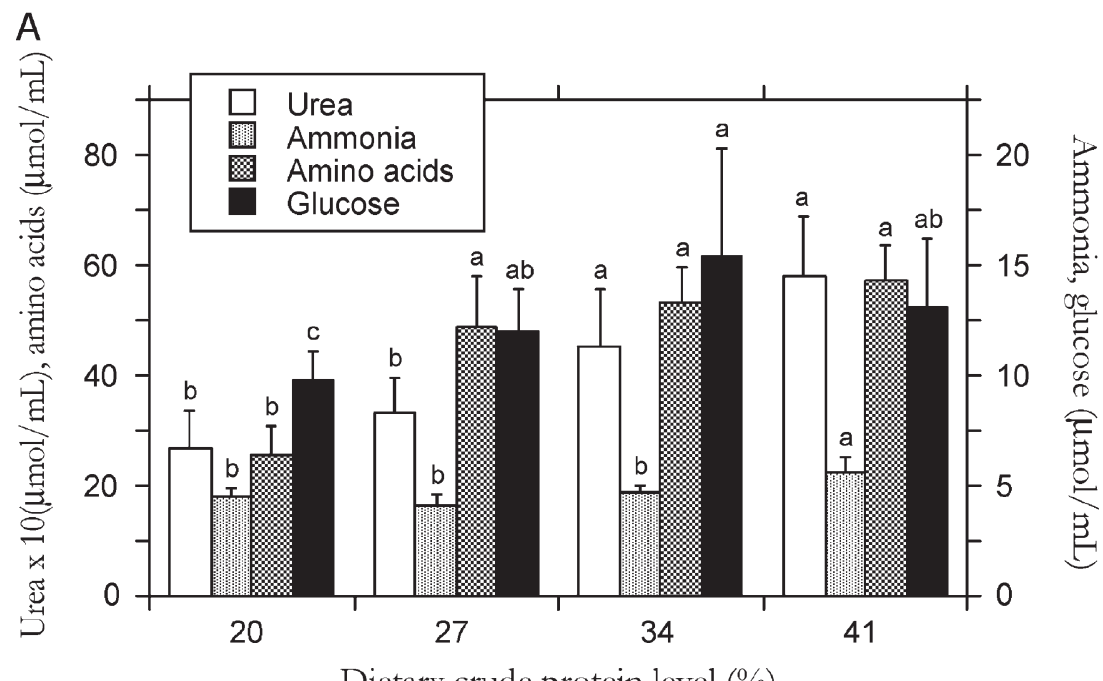

$\mathrm{B}$

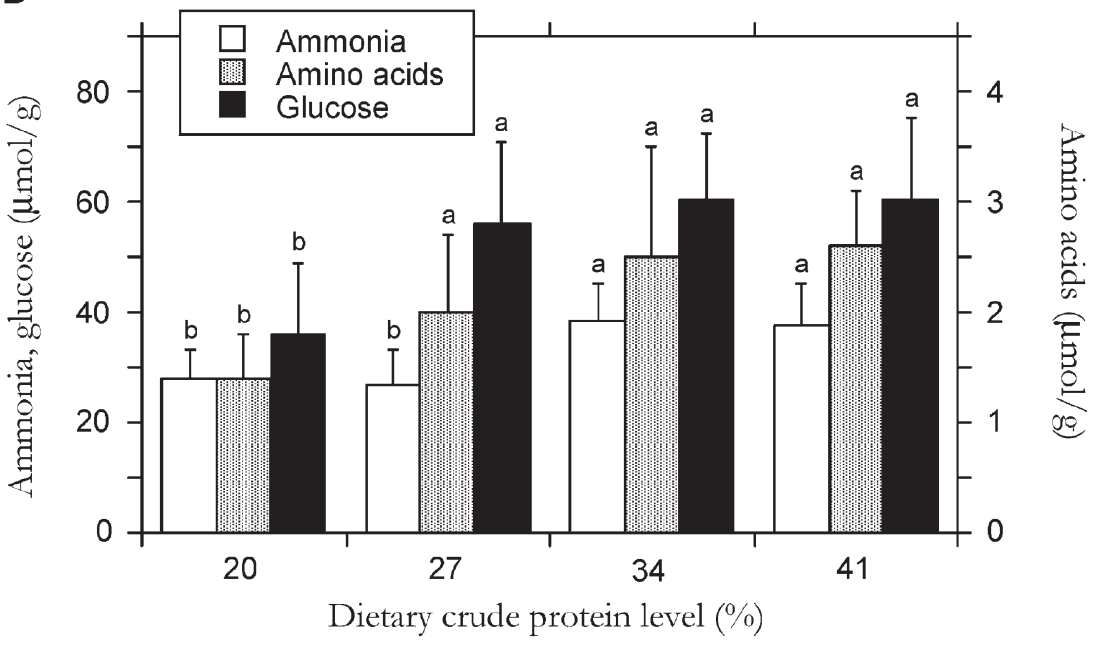

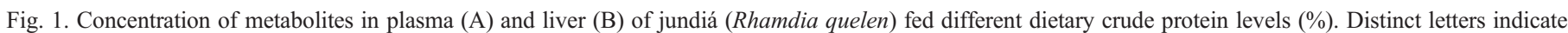
statistical differences at $P<0.05$ (mean \pm S.D.; $n=10$ ). 
fluoride), $1 \mathrm{mM}$ DTT (dithiothreitol) and $250 \mathrm{mM}$ sucrose, in a tissue homogenator (PTA-7 Polytron position 3, $30 \mathrm{~s}$ ). Homogenates were centrifuged at $20,000 \times g$ for $30 \mathrm{~min}$ at $4{ }^{\circ} \mathrm{C}$ and the supernatants were used as source of crude enzyme. Enzymes activities are expressed as $\mathrm{mU} / \mathrm{mg}$ of protein $(1 \mathrm{mU}=1 \mathrm{nmol}$ of enzyme product $/ \mathrm{min}$ ).

Alanine aminotransferase (ALAT) and aspartate aminotransferase (ASAT) were assayed with the Roche-Kits for routine determinations in COBAS MIRA S auto-analyzer. Both reactions were carried out at $340 \mathrm{~nm}$ and $30^{\circ} \mathrm{C}$. Glutamate dehydrogenase (GDH) activity was determined through NADH extinction at $340 \mathrm{~nm}$ for 2 min of reaction (Hochachka et al., 1978). Assay was done at $25{ }^{\circ} \mathrm{C}$ and the reaction mixture contained: $0.05 \mathrm{M}$ imidazole buffer (pH 7.0), 0.1 mM NADH, $1.0 \mathrm{mM} \mathrm{ADP,} 5 \mathrm{mM}$ 2-ketoglutarate, $250 \mathrm{mM}$ ammonium acetate and crude enzyme, previously adjusted to proper protein concentration to a final volume of $1.0 \mathrm{~mL}$. Arginase (ARG) activity was determined at $25^{\circ} \mathrm{C}$ for $30 \mathrm{~min}$ by a colorimetric method (Archibald, 1946). Assay mixture contained: $250 \mathrm{mM}$ arginine, $50 \mathrm{mM}$ Tris buffer pH 8.0 and $1 \mathrm{mM} \mathrm{MnCl}_{2}$ and crude enzyme previously adjusted to the proper protein concentration to a final volume of $1.2 \mathrm{~mL}$.
The enzyme reaction was stopped by addition of $0.1 \mathrm{~mL} 70 \%$ perchloric acid (PCA) and centrifuged at $12,000 \times \mathrm{g}$ for $3 \mathrm{~min}$. Urea was colorimetrically determined in the supernatant at $525 \mathrm{~nm}$ (Rahmatullah and Boyde, 1980).

Total protein content in liver crude extracts was determined at $30{ }^{\circ} \mathrm{C}$ at $600 \mathrm{~nm}$ (Bradford, 1976), using bovine serum albumin as standard.

\subsection{Statistics}

Each tank was considered an experimental unity, and the experimental design was conceived for incomplete blocks considered each fish one replicate $(n=10)$. All data were submitted to ANOVA, $F$-test and Tukey's test to compare the means. The accepted level of significance was $P<0.05$. All data were followed by \pm S.D.

\section{Results}

The mean weight and length, and the weight gain percent of $R$. quelen fed on increasing protein contents in the diet

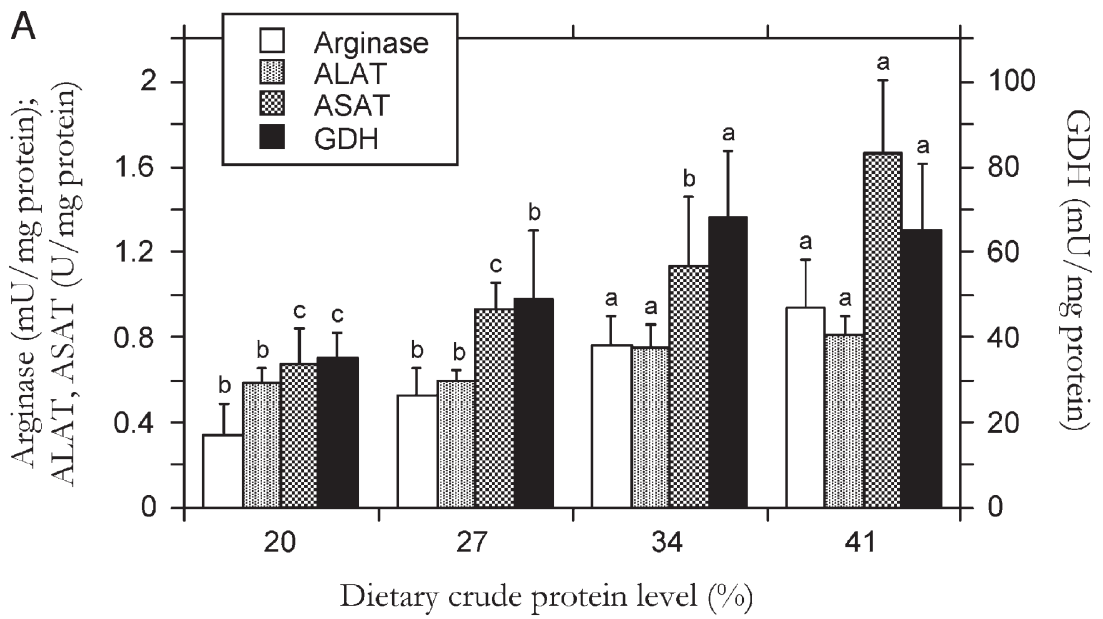

B

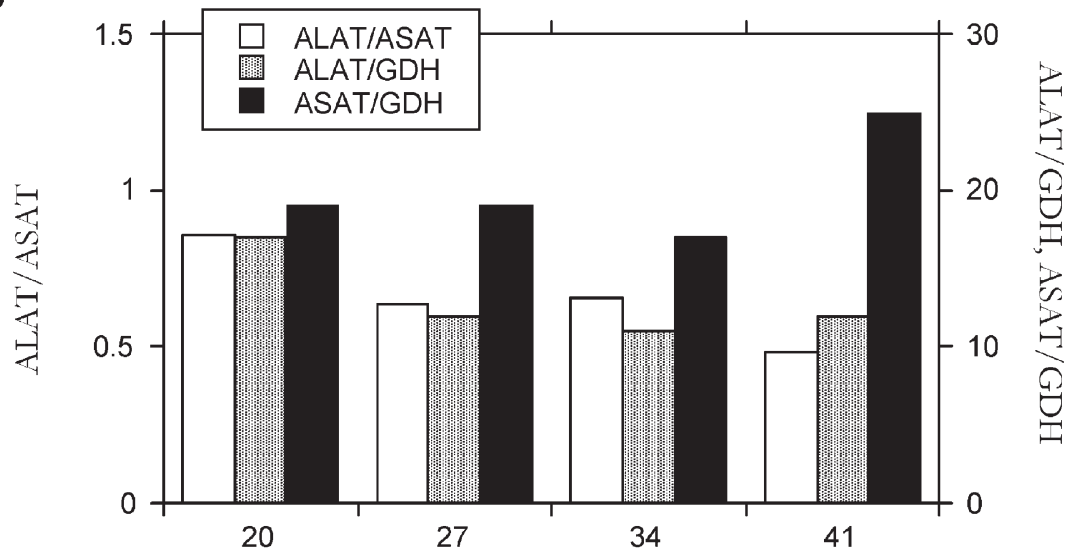

Dietary crude protein level $(\%)$

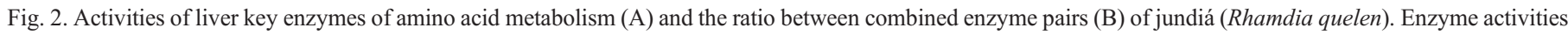

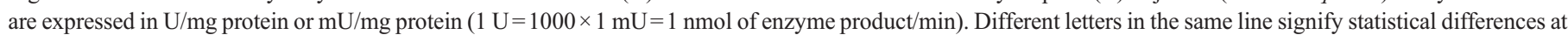
$P<0.05$ (mean \pm S.D.; $n=10$ ). 
significantly increased in the course of 60 days (Table 2). The percentage of weight gain in the fish fed with $27 \%, 34 \%$ and $41 \%$ of CP was about 1.5-, 2- and 3-fold, respectively, over the values observed in the group of fish fed with $20 \%$ of CP. The fish survival was $100 \%$ in all treatments.

Feeding $R$. quelen with different dietary protein levels also promoted significant changes in plasma and liver metabolites (Fig. 1), and enzyme activities involved in protein metabolism (Fig. 2). The concentration of plasma urea followed the increase of protein in the diets. The values rose from 266 to $581 \mu \mathrm{mol} / \mathrm{mL}$. Such high increase was followed by hepatic arginase, which rose from 0.337 to $0.938 \mathrm{mU} / \mathrm{mg}$ of protein. A linear relationship was observed between the levels of dietary protein and activity of hepatic arginase, and levels of dietary protein and plasma urea concentration. The levels of plasma amino acids increased from 25 to $57 \mu \mathrm{mol} / \mathrm{mL}$, and in the liver from 1.4 to $2.6 \mu \mathrm{mol} / \mathrm{mg}$ protein. Both changes were directly related. The concentration of plasma ammonia increased from the average $4.4 \mu \mathrm{mol} / \mathrm{mL}$ at the lower dietary protein to $5.5 \mu \mathrm{mol} / \mathrm{mL}$ at $41 \%$ protein. Similarly, liver ammonia reached the higher concentrations when the fish were fed with 34 or $41 \%$ of $\mathrm{CP}$, rising from about $27 \mu \mathrm{mol} / \mathrm{mg}(20 \%$ and $27 \%$ of $\mathrm{CP})$ to about $38 \mu \mathrm{mol} / \mathrm{mg}$ of tissue protein.

Hepatic enzymes related to metabolism of amino acids were particularly affected. In the group of fish fed with $41 \%$ of CP, activity of ALAT increased nearly $30 \%$ from 587 to $813 \mathrm{mU} / \mathrm{mg}$ protein, ASAT more than doubled (from 687 to $1669 \mathrm{mU} / \mathrm{mg}$ protein), and GDH increased from 35 to $65 \mathrm{mU} / \mathrm{mg}$ protein, compared to fish fed with $20 \%$ of CP. Direct relationship can be observed between the levels of diet protein and the activities of those enzymes. Analysis of the ratios ALAT/ASAT, ALAT/ GDH and ASAT/GDH indicate distinct efficiencies for ALAT, ASAT and GDH in response to the diet protein contents.

\section{Discussion}

In the present study, we used changes in the metabolic profile to predict the ability of $R$. quelen to cope with different dietary protein levels. The difference between the initial and final mean weight of $R$. quelen compared with the changes observed in the body length indicated a significant increase of muscular mass when dietary protein increased (Table 2). This fact can be attributed to the large offering of protein in the food and consequent conversion to body mass. However, a fraction of that protein may have been used as fuel. Relative deficiency of dietary protein can result in low food intake, impairing growth and development (Lovell, 1979), as a consequence of metabolic utilization of non-protein sources followed by amino acid deficiency (Winfree and Stickney, 1981).

The muscle is a pivotal compartment directly linked to the amino acid turnover. This involves protein synthesis or breakdown of those molecules as energetic substrate. Any excess of amino acids can be converted into carbohydrates or, in smaller amounts, to fat (Driedzic and Hochachka, 1978). Metabolism of amino acids involves deamination and transamination reactions. The activities of transaminases and deaminases are useful to evaluate the feeding status in some fish (Alexis and Papapar-
askeva-Papoutsoglou, 1986; Moyano et al., 1991). The rise of hepatic ALAT, ASAT and GDH observed in $R$. quelen fed high protein diets may reflect the use of excess carbon backbones from amino acids to supply energetic demands. Likewise, high protein/carbohydrate ratios in the feeding of Sparus aurata bring about ALAT and ASAT to increase in the liver (Metón et al., 1999). Similar responses were observed in Oncorhynchus mykiss for ALAT and GDH (Sánchez-Muros et al., 1998) and in Anguilla anguilla for GDH (Suárez et al., 1995). The rise in the hepatic activity of protein-metabolizing enzymes when fish were fed high protein diets may denote use of excess dietary amino acids for growth as well as substrate for gluconeogenesis, particularly for GDH and ALAT activities.

Replacement of non-protein energetic nutrients with protein in the feeding of $R$. quelen showed adaptation of the metabolic pathways toward the consumption of proteins as energy source. Thus, substitution of dietary protein for carbohydrates demands special care because there is evidence that an excess of nonprotein energy (carbohydrates and lipids) can impair growth (Winfree and Stickney, 1981; Johnson et al., 2002). The use of ingested protein as energy source varies between $41 \%$ and $85 \%$ among fish (Van Waarde, 1983). Therefore, the ratio protein/ carbohydrate must be adjusted to prevent the breakdown of amino acids just as energy substrate.

In the present study, the high contents of dietary protein, and the consequent low levels of carbohydrates, increased transaminations, deamination and nitrogenous metabolites in $R$. quelen. Apparently the increase of plasma glucose observed when the level of dietary carbohydrate decreased is inconsistent. Two possibilities are raised to explain such a fact, gluconeogenesis or lower digestibility of sugar from corn and wheat bran as higher contents are introduced. In spite of all enzyme activities were increased with the dietary protein, GDH, ASAT and ALAT were respectively more demanded. The enzymes GDH and ASAT are fully involved in amino acid metabolism; however, carbon residues directly from glycolysis can also supply ALAT. Therefore, by comparing ratios among transaminases and GDH in the liver of $R$. quelen it was possible to emphasize that the gluconeogenic processes were exacerbated. Consistently, higher levels of plasma and liver glucose were found in the fish fed with higher $\mathrm{CP}$ diets. Changes in nitrogen metabolism related enzymes associated with high increase of glucose observed in liver are very suggestive of gluconeogenesis due to $\mathrm{CP}$ increase in the diets. The increase in GDH, ASAT and ALAT denotes catabolism of amino acids and is associated with increased nitrogenous excretion. The augment of protein breakdown in fish, resulting in increase of plasma ammonia concentration, was previously observed in Bidyanus bidyanus and Dicentrarchus labrax (Yang et al., 2002; Peres and Oliva-Teles, 2001). Excess of ammonia is promptly excreted through the gills (Van Waarde et al., 1983). In some fish species, particularly under adverse environmental conditions when ammonia excretion is impaired, urea excretion is triggered (Wood et al., 1995; Saha and Ratha, 1998). High levels of environmental ammonia should contribute to plasma ammonia increased. However, the high quality of water in the trials prevented such undesirable effect. Therefore, the increase of ammonia and urea observed in R. quelen were certainly due to the increase of protein catabolism. 
Urea cycle induction can be observed in fasting (Walsh et al., 1990), dehydratation (Polez et al., 2003), confinement stress (Hopkins et al., 1995), water alkalinity (Polez et al., 2004), and external ammonia concentration (Saha and Ratha, 1994). Also, the increase of protein content in diets can enhance the activity of urea cycle enzymes in fish (Chiu et al., 1986). Arginase activity, urea excretion and plasma urea concentration in turbot (Psetta maxima) and rainbow trout (O. mykiss) are directly correlated to dietary arginine (Gouillou-Coustans et al., 2002; Fournier et al., 2003). Thus, enhancing of liver arginase activity and the plasma urea content in $R$. quelen fed high protein diets may result from increasing concentration of dietary arginine.

Plasma glucose and amino acids tend to increase in fish fed high protein levels as observed in O. mykiss (Lone et al., 1982) and European eel (Suárez et al., 1995). In the present study, the surplus of protein in the feeding of $R$. quelen can be inferred from the amino acids concentration in the tissues. This fact can be also associated to increased absorption of amino acids from protein digestion as stressed by Yamamoto et al. (1999). On the other hand, the increase of non-protein digestible energy enhances nitrogen retention (Engin and Carter, 2001). Although, the increase of amino acids in the plasma of jundiá followed by plasma glucose is likely driven to the synthesis of new proteins and/or sugar, the increase of ALAT, ASAT and GDH suggests protein catabolism at high protein levels in the diet. Blood and tissue levels of amino acids are dependent on factors such as digestion efficiency, fish size, bulk and composition of feeding, and temperature (Grove et al., 1981; Darcy, 1984). In this case, the rise of plasma amino acids versus dietary protein increase is likely due to enhancement of digestion (Lundstedt et al., 2002).

Increase of nitrogenous excretion is a consequence of using amino acids as energetic compounds (Hidalgo and Alliot, 1988; Kim et al., 1991). A rise in the ratio of protein/carbohydrate plus lipid increases nitrogen excretion in trout (Rychly, 1980). A direct relationship between protein intake and ammonia excretion has been found in fish ( $\mathrm{Li}$ and Lowell, 1992; Chakraborty and Chakraborty, 1998), and ammonia excretion has been proposed as index for comparing the efficiency of dietary protein utilization among rainbow trout of different strains (Ming, 1985). Rychly (1980) reported that nitrogen excretion increased with high protein and low carbohydrate content in the diet. Therefore, the high catabolism of protein observed in $R$. quelen indicates the importance of carbohydrate addition in the feeding of this species for the purpose of sparing protein.

In conclusion, levels of ALAT, ASAT, GDH and arginase were significantly affected by diet composition in $R$. quelen and can be used as a metabolic tool for assessing the proper concentration of dietary protein in the feeding of this species. The ratios among transaminases and GDH enabled evaluating the metabolic preference in stated circumstances. The activity of arginase associated to urea and ammonia quantification is an easy form of establishing the surplus of nitrogen source in the feeding of $R$. quelen. In addition, the knowledge of the proper ratio protein/carbohydrate in the fish feeding is fundamental to establish the optimal nitrogen content in the food, to prevent nitrogen waste and to avoid environmental damages. The ratio protein/energy in the $R$. quelen diets seems to be specific and further studies concerning types and sources of carbohydrates and lipids to replace protein as energy source are necessary.

\section{References}

Alexis, M.N., Papaparaskeva-Papoutsoglou, E., 1986. Aminotransferase activity in the liver and white muscle of Mugil capito fed diets containing different levels of protein and carbohydrate. Comp. Biochem. Physiol., B 83, 245-249.

Archibald, R.M., 1946. Determination of citrulline and alantoin and demonstration of citrulline in blood plasma. J. Biol. Chem. 156, 121-142.

Baanante, I.V., García de Frutos, P., Bonamusa, L., Fernández, F., 1991. Regulation of fish glycolysis-gluconeogenesis: role of fructose 2,6 P2 and PFK-2. Comp. Biochem. Physiol., B 100, 11-17.

Ballantyne, J.S., 2001. Amino acid metabolism. Fish Physiol. 20, 77-107.

Bidinotto, P.M., Moraes, G., 2000. Induced changes in the amylohydrolytic profile of the gut of Piaractus mesopotamicus (Holmberg, 1885) fed different contents of soluble carbohydrate; its correlation with metabolic aspects. Rev. Ictiol. Argentina 8, 47-51.

Bonamusa, L., Gárcia de Frutos, P., Fernández, F., Baanante, I.V., 1992. Nutritional effects on key glycolytic-gluconeogenic enzyme activities and metabolite levels in the liver of the teleost fish Sparus aurata. Mol. Mar. Biol. Biotechnol. 1, 113-125.

Bradford, M.M., 1976. A rapid and sensitive method for the quantitation of microgram quantities of protein utilizing the principle of protein-dye binding. Anal. Biochem. 72, 248-254.

Caseras, A., Metón, I., Fernández, F., Baanante, I.V., 2000. Glucokinase gene expression is nutritionally regulated in the liver of gilthead seabrean (Sparus aurata). Biochim. Biophys. Acta 1493, 135-141.

Chakraborty, S.C., Chakraborty, S., 1998. Effect of dietary protein level on excretion of ammonia in Indian major carp, Labeo rohita, fingerlings. Aquac. Nutr. 4, 47-51.

Chiu, Y.N., Austic, R.E., Rumsey, G.L., 1986. Urea cycle activity and arginine formation in rainbow trout (Salmo gairdneri). J. Nutr. 116, 1640-1650.

Copley, N.G., 1941. Alloxan and ninhydrin test. Analyst 66, 492-493.

Cowey, C.B., Walton, M.J., 1989. Intermediary metabolism. In: Halver, J.E. (Ed.), Fish Nutrition. Academic Press, San Diego, pp. 259-329.

Cowey, C.B., de la Higuera, M., Adron, J.W., 1977. The effect of dietary composition and of insulin on gluconeogenesis in rainbow trout (Salmo gairdneri). Br. J. Nutr. 38, 385-395

Darcy, B., 1984. Availability of amino acids in monogastric animals. Diabetes Metab. 10, 121-133.

De Long, D.C., Halver, J.E., Mertz, E.T., 1958. Nutrition of salmonoid fishes: VI. Protein requirements of Chinook salmon at two water temperatures. J. Nutr. 65, 589-599.

Do Carmo de Sá, M.V.S., Fracalossi, D.M., 2002. Exigência protéica e relação energia/proteína para alevinos de piracanjuba Brycon orbignyanus. Rev. Bras. Zootec. 31, 1-10.

Driedzic, W.R., Hochachka, P.W., 1978. Metabolism in fish during exercise. Fish Physiol. VII, 503-543.

Engin, K., Carter, C.G., 2001. Ammonia and urea excretion rates of juvenile Australian Short-finned eel (Anguilla australis australis) as influenced by dietary protein level. Aquaculture 194, 123-136.

Fournier, V., Gouillou-Coustans, M.F., Métailler, R., Vachot, C., Moriceau, J., Le Delliou, H., Huelvan, C., Desbruyères, E., Kaushik, S.J., 2003. Excess dietary arginine affects urea excretion but does not improve $\mathrm{N}$ utilization in rainbow Oncorhynchus mykiss and turbot Psetta maxima. Aquaculture 217, 559-576.

Garling, D.L., Wilson, R.P., 1976. Optimum dietary protein to energy ratio for channel catfish fingerlings, Ictalurus punctatus. J. Nutr. 116, 1368-1375.

Gentzkow, C.J., Masen, J.M., 1942. An accurate method for the determination of blood urea nitrogen by direct nesslerization. J. Biol. Chem. 143, 531-544.

Gouillou-Coustans, M.F., Fournier, V., Métailler, R., Vachot, C., Desbruyères, E., Huelvan, C., Moriceau, J., Le Delliou, H., Kaushik, S.J., 2002. Dietary arginine degradation is a major pathway in ureagenesis in juvenile turbot (Psetta maxima). Comp. Biochem. Physiol., A 132, 305-319.

Grove, D.J., Loizides, L.G., Nott, J., 1981. Satiation amount, frequency of feeding and gastric emptying rate in Salmo gairdner. J. Fish Biol. 12, 507-516. 
Hidalgo, F., Alliot, E., 1988. Influence of water temperature on protein utilization in juvenile sea bass, Dicentrachus labrax. Aquaculture 72, 115-129.

Hochachka, P.W., Guppy, M., Guderley, H.E., Storey, K.B., Hulbert, W.C., 1978. Metabolic biochemistry of water vs air-breathing fishes: Muscle enzymes and ultrastructures. Can. J. Zool. 56, 736-750.

Hopkins, T.E., Wood, C.M., Walsh, P.J., 1995. Interactions of cortisol and nitrogen metabolism in the ureogenic gulf toadfish Opsanus beta. J. Exp. Biol. 198, 2229-2235.

Houlihan, D.F., Mathers, E., Foster, A.R., 1993. Biochemical correlates of growth rate in fish. In: Rankin, J.C., Jensen, F.B. (Eds.), Fish Ecophysiology. Chapman \& Hall, London, pp. 45-72.

Jauncey, K., 1982. The effects of varying dietary protein level on the growth, food conversion, protein utilization, and body composition of juvenile tilapias Sarotherodon mossambicus. Aquaculture 27, 43-45.

Johnson, E.G., Watanabe, W.O., Ellis, S.C., 2002. Effects of dietary lipid levels and energy: Protein ratios on growth and feed utilizations of juvenile Nassau grouper fed isonitrogenous diets at two temperatures. N. Am. J. Aquac. 64, 47-54.

Kim, K., Kyes, T.B., Amundson, C.H., 1991. Purified diet development and reevaluation of the dietary protein requirement of fingerling rainbow trout (Oncorhynchus mykiss). Aquaculture 96, 57-67.

Lall, S.P., Kaushik, S.J., LeBail, P.Y., Plisetskaya, E., 1994. Quantitative arginine requirement of Atlantic salmon (Salmo salar) reared in seawater. Aquaculture 124, 13-25.

Li, M., Lowell, R.T., 1992. Effect of dietary protein concentration on nitrogenous waste in intensively fed catfish ponds. J. World Aquac. Soc. 23, 122-127.

Lone, K.P., Ince, B.W., Matty, A.J., 1982. Changes in the blood chemistry of rainbow trout, Salmo gairdneri fish, in relation to dietary protein level, and an anabolic steroid hormone, ethylestrenol. J. Fish Biol. 20, 597-606.

Lovell, R.T., 1979. Factors affecting voluntary food consumption by channel catfish. Proc. World Symp. Finfish Nutr. Fishfeed Technol. 1, 555-564.

Lundstedt, L.M., Melo, J.F.B., Santos-Neto, C., Moraes, G., 2002. Diet influences proteolytic enzyme profile of the South American catfish Rhamdia quelen. Proceedings of International Congress on the Biology of Fish, Biochemistry and Physiology Advances in Finfish Aquaculture, Vancouver, Canada, pp. 65-71.

Lundstedt, L.M., Melo, J.F.B., Moraes, G., 2004. Digestive enzymes and metabolic profile of Pseudoplatystoma corruscans (Teleostei: Siluriformes) in response to diet composition. Comp. Biochem. Physiol., B 137, 331-339.

Melo, J.F.B., Radünz-Neto, J., Silva, J.H.S., Trombetta, C.G., 2002. Desenvolvimento e composição corporal de alevinos de jundiá (Rhamdia quelen) alimentados com dietas contendo diferentes fontes de lipídios. Rev. Ciênc. Rural 32, 323-327.

Metón, I., Mediavilla, D., Casearas, A., Cantó, E., Fernández, F., Baanante, I.V., 1999. Effect of diet composition and ration size on key enzyme activities of glycolysis-gluconeogenesis, the pentose phosphate pathway and amino acid metabolism in liver of gilthead sea bream (Sparus aurata). Br. J. Nutr. 82, $223-232$.

Metón, I., Egea, M., Baanante, I.V., 2003. New insights into regulation of hepatic glucose metabolism in fish. Recent Res. Dev. Biochem. 4, 125-149.

Ming, F.W., 1985. Ammonia excretion rate as an index for comparing efficiency of dietary protein utilization among rainbow trout (Salmo gairdneri) of different strains. Aquaculture 46, 27-35.

Moon, T.W., Foster, G.D., 1995. Tissue carbohydrate metabolism, gluconeogenesis and hormonal and environmental influences. In: Hochachka, P.W., Mommsen, T.P. (Eds.), Metabolic Biochemistry, Biochemistry and Molecular Biology of Fishes, vol. 4. Elsevier, Amsterdan, pp. 65-100.

Moraes, G., Bidinotto, P.M., 2004. Digestive proteases of pacu, Piaractus mesopotamicus fed on distinct protein-starch diets. J. Appl. Aquac. 15, 197-207.

Moyano, F.J., Cardente, G., de la Higuera, M., 1991. Nutritive and metabolic utilization of proteins with glutamic acid content by the rainbow trout $\mathrm{On}$ corhynchus mykiss. Comp. Biochem. Physiol., A 100, 759-762.
Ogata, H., Arai, S., 1985. Comparison of free amino acid contents in plasma, whole blood and erythrocytes of carp, coho salmon, rainbow trout, and channel catfish. Bull. Jpn. Soc. Sci. Fish. 51, 1181-1186.

Peres, H., Oliva-Teles, A., 2001. Effect of dietary protein lipid level on metabolic utilization of diets by European sea bass (Dicentrarchus labrax) juveniles. Fish Physiol. Biochem. 25, 269-275.

Piaia, R., Radünz-Neto, J., 1997. Avaliação de diferentes fontes protéicas sobre o desempenho inicial de larvas do jundiá (Rhamdia quelen). Ciênc. Rural 27, 319-323.

Polez, V.L.P., Moraes, G., Santos-Neto, C., 2003. Different biochemical strategies of two Neotropical fish to cope with the impairment of nitrogen excretion during air exposure. Braz. J. Med. Biol. Res. 36, 279-285.

Polez, V.L.P., Iwama, G.W., Moraes, G., 2004. Ureotelism is inducible in the Neotropical freshwater Hoplias malabaricus (Teleostei, Erythrinidae). Braz. J. Biol. 64, 101-113.

Rahmatullah, M., Boyde, T.R.C., 1980. Improvements in the determination of urea using diacetyl monoxime: methods with and without deproteinization. Clin. Chim. Acta 107, 3-9.

Rychly, J., 1980. Nitrogen balance in trout. II. Nitrogen excretion after feeding diets with varying protein and carbohydrate levels. Aquaculture 20, 343-350.

Saha, N., Ratha, B.K., 1994. Induction of ornithine-urea cycle in a freshwater teleost, Heteropneustes fossilis, exposed to high concentrations of ammonium chloride. Comp. Biochem. Physiol., B 108, 315-325.

Saha, N., Ratha, B.K., 1998. Ureogenesis in Indian air-breathing teleosts: adaptation to environmental constraints. Comp. Biochem. Physiol., A 120, 195-208.

Sánchez-Muros, M.J., Gárcia-Rejón, L., Gárcia-Salguero, L., de la Higuera, M., Lupiánes, J.A., 1998. Long-term nutritional effects on the primary liver and kidney metabolism in raimbow trout. Adaptive response to starvation and high-protein, carbohydrate-free diet on glutamate dehydrogenase and alanine aminotransferase kinetics. Biochem. Cell. Biol. 30, 55-63.

Steffens, W., 1989. Principles of Fish Nutrition. Ellis Horwood Ltd, New York, USA. 384 pp.

Stone, D.A., Allan, G.L., Anderson, A.J., 2003. Carbohydrate utilization by juvenile silver perch, Bidyanus bidyanus (Mitchell). III. The protein-sparing effect of wheat starch-based carbohydrates. Aquac. Res. 34, 123-134.

Suárez, M.D., Hidalgo, M.C., García Gallego, M., Sanz, A., de la Higuera, M., 1995. Influence of relative proportions of energy yielding nutrients on liver intermediary metabolism of the European eel. Comp. Biochem. Physiol., A $111,421-428$.

Van Waarde, A., 1983. Aerobic and anaerobic ammonia production by fish. Comp. Biochem. Physiol., B 74, 675-684.

Van Waarde, A., Van Den Thillart, G., Kesbeke, F., 1983. Anaerobic energy metabolism of the European eel, Anguilla anguilla L. J. Comp. Physiol., B 149, 469-475.

Walsh, P.J., Danulat, E., Mommsen, T.P., 1990. Variation in urea excretion in the gulf toadfish Opsanus beta. Mar. Biol. 106, 323-328.

Winfree, R.A., Stickney, R.R., 1981. Effects of dietary protein and energy on growth, feed conversion efficiency and body composition of Tilapia aurea. J. Nutr. 111, 1001-1012.

Wood, C.M., 1993. Ammonia and urea metabolism and excretion. In: Evans, D.H. (Ed.), The Physiology of Fish. CRC Press INC., Boca Raton, Florida. $425 \mathrm{pp}$.

Wood, C.M., Hopkins, T.E., Hogstrand, C., Walsh, P.J., 1995. Pulsatile urea excretion in the toadfish Opsanus beta: an analysis of the rates and routes. J. Exp. Biol. 198, 1729-1741.

Yamamoto, T., Unuma, T., Akiyama, T., 1999. The influence of dietary protein and fat levels on tissue free amino acid levels of fingerling rainbow trout (Oncorhynchus mykiss). Aquaculture 182, 353-372.

Yang, S., Liou, C., Liu, F., 2002. Effects of dietary protein level on growth performance, carcass composition and ammonia excretion in juvenile silver perch (Bidyanus bidyanus). Aquaculture 213, 363-372. 